\title{
THE MORTGAGEE REMEDIES OF ENTRY INTO POSSESSION AND RECEIVERSHIP: ANCIENT EQUITY MEETS MODERN STATUTE
}

\author{
Daniel Armstrong*
}

This article comprehensively catalogues and critiques the differences between the mortgagee remedies of entry into possession and receivership. In particular, the article looks at differences in how rights, duties, powers and liabilities of a mortgagor in possession as opposed to a receiver affect the choice of remedy. The author concludes that recent changes to the law in New Zealand have undermined the traditional advantages of receivership, and that equity is currently re-emphasising the rights of mortgagors.

\section{INTRODUCTION}

Following the abolishment of foreclosure in New Zealand, ${ }^{1}$ mortgagees of land usually enforce their security through sale. The remedies of possession and receivership also allow mortgagees to recover loan proceeds through the interception of rents and profits from the mortgage property. These two remedies are similar, yet the applicable laws are generally treated separately. Furthermore, the institutionalised mantra that receivership is the better remedy has arguably led to receivership law being valued while the archaic laws of mortgagee possession are comparatively disregarded. This article seeks to re-evaluate that inherited wisdom by contrasting and comparing various aspects of mortgagee possession and receivership law with the practical goal of providing information pertinent to a mortgagee's choice of remedy. The recent changes to these bodies of law are also placed in their historical context by analysing how they perpetuate equity's centuries-old oscillation between championing the rights of mortgagees and mortgagors.

* This paper was submitted in fulfilment of the LLB (Hons) requirements at Victoria University in 1999.

1 Conveyancing Ordinance 1842 (UK), cl 41. Today, see the Property Law Act 1952, s 89 (PLA 1952). 
This article only deals with "charge mortgages", under which mortgagees acquire no estate $^{2}$ and with receivers appointed by the mortgagee ${ }^{3}$ as the mortgagor's agent ${ }^{4}$ to hold powers of management. ${ }^{5}$

\section{A BRIEF HISTORY}

The laws of mortgagee possession and receivership developed through equity's struggle to balance the rights of mortgagees and mortgagors. Ironically many equitable rules themselves became the source of inequity, and as later Chancery Courts sought to avoid, rather than remove, these entrenched rules, the balance tilted back and forth.

Under common law mortgagees, as legal title-holders, could take possession of mortgaged land immediately, ${ }^{6}$ without notice, ${ }^{7}$ and without default by the mortgagor. ${ }^{8}$ Despite the potential for injustice, the Chancery Courts would, "... never interfere to prevent the mortgagee from taking possession." 9 This hesitancy unexplained, equity instead evolved the solution of holding mortgagees in possession to high standards of behaviour, requiring them to answer not only for the land's actual income, but also for what might have been obtained but for their wilful default. ${ }^{10}$ This equitable rule was universally characterised as "onerous" and so equity, ameliorating its own rule, came to

2 Only charge mortgages may be registered. The PLA 1952, s 100 states that registered mortgages shall "have effect as security, but shall not operate as a transfer of the estate or interest charged." The Second Schedule contains several forms for a registered mortgage, all of which operate by way of charge.

3 As opposed to court-appointed receivers. See Judicature Act 1908, s 16; Evans v Orr [1923] NZLR 769 (SC); Securities Act 1978, s 49(3)(f) (relevant to the application of a trustee or statutory supervisor). The court will only appoint receivers as a last resort: Steel v Mataoki International Ltd (1988) 4 NZCLC 64,710 (HC).

4 In New Zealand it is statutorily presumed that receivers are appointed as agent of the mortgagor, not the mortgagee. See Receiverships Act 1993, s 6(3) (RA 1993), reversing the presumption under the general law.

5 Distinguishing them from receivers simpliciter, who only receive and distribute income. See Re Manchester and Milford Railway Company (1880) 14 Ch D 645, 653 per Jessel MR (CA).

6 Possession could be taken "before the ink is dry on the mortgage": Four Maids Ltd v Dudley Marshall (Properties) Ltd [1957] 1 Ch 317, 320, per Harman J. See also Birch v Wright (1786) 1 TR 378, 383 per Buller J.

7 Doe d Fisher $v$ Giles (1829) 5 Bing 421.

8 Doe d Roylance v Lightfoot (1841) 8 M\&W 553; Green v Burns (1879) 6 L R Ir 173.

9 Marquis of Cholmondeley v Lord Clinton (1817) 2 Mer 171, 359 per Sir William Grant; London Permanent Benefit Building Society v De Baer [1968] 1 All ER 372.

10 See below subsection VI D: A Mortgagee's Duty Upon Entering Into Possession. 
favour devices, including receivership, which allowed mortgagees to gain the benefits of possession while avoiding this liability. ${ }^{11}$

Most recently, major statutory activity occurred in this area in 1993 when the Receiverships Act 1993 (RA 1993) and a new Part VIIA of the Property Law Act 1952 (PLA), concerning mortgagee possession, emerged from the Companies (Ancillary Provisions) Bill.

This article now embarks upon the task of cataloguing and critiquing the differences between the mortgagee remedies of possession and receivership. Attention first falls on the initiation stage, where despite the recent coterminous review of the applicable statutes, unjustifiable and technical differences between the remedies remain.

\section{INITIATING POSSESSION AND RECEIVERSHIP}

\section{A When Does the Entitlement Arise?}

The first reference point is the mortgage contract, which can specify exactly when possession and receivership may be exercised. However, in the absence of such words possession is permitted only, "upon default in payment...". 12 This reflects the equitable stance that securing repayment is a mortgage's ultimate purpose; ${ }^{13}$ it underlies the mortgagor's equitable right of redemption, ${ }^{14}$ and is justifiably emphasised in this context. Strangely, considering equity's traditional preference for devices which allow mortgagees to avoid the remedy of possession, the receivership remedy is not automatically available upon default in repayment, ${ }^{15}$ and an amendment to correct this discrepancy would appear justified. ${ }^{16}$

11 See generally Gaskell v Gosling [1896] 1 QB 669, 691-693 per Rigby LJ (CA).

12 Land Transfer Act 1952, s 106 (LTA 1952). Compare the Property Law Act 1925 (UK), ss 95(4), 87(1), which simply grants mortgagees the full common law right of possession.

13 See Downsview Nominees Ltd v First City Corporation [1993] 1 NZLR 512, 522 per Lord Templeman (PC).

14 Whereby equity allows a mortgagor to repay the loan at any time, regardless of a contractual time limit. See PLA 1952, s 81.

15 Compare, for example, Law of Property Act 1925 (UK), s101; New South Wales (Conveyancing) Act 1919 (NSW), s 109(1)(c).

16 See New Zealand Law Commission (Kenneth Keith) "A New Property Law Act" (Law Commission, Wellington, 1994) Report No 29, Draft Property Law Act, Fourth Schedule cl 10, 22 ["NZLC R29"]. 
The premature exercise of an entitlement can render the mortgagee or receiver liable for trespass, ${ }^{17}$ conversion, or breach of contract. ${ }^{18}$ The High Court can investigate the validity of a receiver's appointment ${ }^{19}$ and may restrain by injunction a premature entry into possession.

\section{B A Mortgagee's Duty When Choosing Whether to Exercise an Entitlement}

If a mortgage ranks equally with other securities, the mortgagee may owe a fiduciary duty to exercise their remedies in the security-holders' collective best interests. ${ }^{20}$ Otherwise the decision is restrained only by the need to act in good faith and without oppression (see below section VI: Duties), ${ }^{21}$ a duty possibly breached if they appoint an incompetent receiver. ${ }^{22}$

\section{Notice Requirements}

A mortgagee cannot enter into possession until they serve the mortgagor with notice under section 92 of the PLA notifying them of the default and their right to remedy it. ${ }^{23}$ Belying the section's importance, it cannot be contractually avoided. ${ }^{24}$ Yet section 92 can be ignored when appointing a receiver ${ }^{25}$ even though such appointment may have drastic consequences, triggering default provisions in the mortgagor's other credit contracts or raising the presumption that a corporate mortgagor cannot pay its debts. ${ }^{26}$

17 See R Jaffe Ltd v Jaffe (No 2) [1932] NZLR 195 (SC).

18 See ANZ Banking Group (NZ) Ltd v Gibson [1986] 1 NZLR 556, 560 per Richardson J (CA).

19 RA 1993, s 34(2)(c).

20 Re Maskelyne British Typewriter Ltd [1988] 1 Ch 133 (CA); Re Slogger Automatic Feeder Co Ltd [1915] 1 Ch 478 (both relating to the appointment of receivers).

21 Quennell v Maltby [1979] 1 All ER 568, 571 per Denning MR (regarding entry into possession); Shamji v Johnson Matthey Bankers Ltd [1986] BCLC 278, 284 per Hoffmann J; Terry Clark \& Associates Pty Ltd $v$ Carez Nominees Pty Ltd (1994) 13 ACSR 314 (SA:SC) (regarding the appointment of a receiver). See generally Trent Petherick "Can a Mortgagee Simply Decide If and When to Sell?" [1996] NZLJ 173.

22 Shamji v Johnson Matthey Bankers Ltd [1986] BCLC 278, 283 per Hoffmann J.

23 See Jaffe v Premier Motors Ltd [1960] NZLR 146, 148 per Shorland J (SC).

24 PLA 1952, s 92(7)

25 RA 1993, s 9.

26 Companies Act 1993, s 287(c). This is one of the pre-requisites to liquidation: Companies Act 1993, s 241(4). 
Swift appointment makes sense when a receiver is appointed by a debenture-holder ${ }^{27}$ holding a floating charge over a company's entire assets. In this context, the secured assets, such as trading stock, can be moved outside the ambit of the floating charge by ordinary sale, and so the law allows receivers to move in after a "reasonable time" (which can be brief). ${ }^{28}$ But when the security is a fixed, registered charge-mortgage over land, the need for swift appointment diminishes. The mortgagee's fixed, registered interest is not lost if the land is sold, and land is less readily damaged or "lost" than other property.

Regrettably the Receiverships Act 1993 applies to all receiverships regardless of the property and security involved. ${ }^{29}$ The PLA avoids this mistake by requiring section 92 notice only when possession is claimed over land; section 9 of the Receiverships Act 1993 should draw the same distinction. ${ }^{30}$

\section{Methods of Execution}

Mortgagees can take possession by obtaining a court order, ${ }^{31}$ by receiving the land's rents or profits, ${ }^{32}$ or by physically entering the premises. ${ }^{33}$ Physical possession may attract criminal sanction if taken forcibly, ${ }^{34}$ but is still effective against the mortgagor. ${ }^{35}$ To acquire the full powers, duties and liabilities of mortgagees in possession they must

27 Debenture-holders and debenture-grantors hold essentially the same positions as mortgagees and mortgagors: Downsview Nominees Ltd v First City Corporation [1993] 1 NZLR 513, 521 per Lord Templeman (PC).

28 This rule is established in the case of on-demand debentures: Toms $v$ Wilson (1863) 4 B\&S 455. In the case of default on repayment, "reasonable time" only means time to complete the mechanics of payment; ANZ Banking Group (NZ) Ltd v Gibson [1986] 1 NZLR 556, 565 per Richardson J (CA); Bank of Baroda v Panessar [1986] 3 All ER 751, 760 per Walton J. See also William Conklin and Jodi Morrison "Public Issues in a Private Law World: The Appointment of a Receiver as a Case Study" (1988) 26 Osgoode Hall LJ 45, asserting that even the reasonable time rule does not prevent procedural and substantive injustice.

29 An approach advocated by the New Zealand Law Commission (Sir Owen Woodhouse) "Company Law: Reform \& Restatement" (Law Commission, Wellington, 1989) Report No 9, para 112, 27, para 750, 380 ["NZLC R9"].

30 See the suggestions in NZLC R29, above $\mathrm{n} 16$, para 23, 8 and para 58, 18.

31 For a review of the various proceedings available to a mortgagee see Peter Young Law of Mortgages of Land in New Zealand (1 ed, Wellington, Butterworths, 1995) para 22.37, 366-367.

32 LTA 1952, s 106. For example, by instructing tenants to pay rent to a collector employed by the mortgagee.

33 Lysnar v National Bank of New Zealand Ltd (No 2) [1936] NZLR 541 per Kennedy J (CA).

34 Crimes Act 1961, s 91.

35 Lows v Telford (1876) 1 App Cas 414 (HL). 
actually take the management of the property out of the mortgagor's hands. ${ }^{36}$ This rule arose from equity's hesitancy to find that mortgagees had entered into possession, a further example of equity ameliorating the harsh consequences of other equitable rules. ${ }^{37}$

Receivers are appointed when they receive written notice of their appointment and tacitly or expressly accept it. ${ }^{38}$

\section{E Personal Qualifications}

Australian receivers must belong to a recognised body of professional accountants, have a university degree, and be experienced at winding up companies. ${ }^{39}$ The New Zealand Law Commission supported similar positive requirements, ${ }^{40}$ but apparently, "no case was made out for such occupational regulation." 41 Consequently New Zealand only applies negative criteria, ${ }^{42}$ disqualifying people for presumed bias, ${ }^{43}$ a history of financial mismanagement, ${ }^{44}$ presumed incompetence at managing property, ${ }^{45}$ or a proven unwillingness or inability to observe the statutory duties demanded of directors, receivers

36 Noyes v Pollock (1886) 32 Ch D 53 (CA); Overden v Prins (1897) 16 NZLR 224 (CA).

37 See above section II: A Brief History.

38 RA 1993, s 6(2). Other methods can be specified, but they must be strictly conformed to: $B N Z$ Finance Ltd v McKenna (1989) 4 NZCLC 65,327, 65,329-330 (HC); Wrights Hardware Pty Ltd v Evans (1988) 13 ACLR 631 (WA:SC).

39 Peter Blanchard and Michael Gedye The Law of Company Receiverships in New Zealand and Australia (2 ed, Butterworths, Wellington, 1994) para 4.17, 84 .

40 NZLC R9, above n 29, Draft Property Law Amendment Act, cl 104AD(1), 394

41 (10 August 1993) 537, NZPD, 17330 per Hon D Graham (Minister of Justice).

42 RA 1993, s 5(1). The High Court can waive these restrictions.

43 This disqualifies the mortgagee, current or recent directors of the mortgagor or mortgagee, and people with a current or recent interest in shares of the mortgagor or mortgagee.

44 This disqualifies undischarged bankrupts and discharged bankrupts prohibited by the High Court under the Insolvency Act 1967, s 111(1)(c) from directing or managing a company.

45 This disqualifies people subject to compulsory treatment orders under the Mental Health (Compulsory Assessment and Treatment) Act 1992, people whose property is subject to a temporary Family Court protection order or temporary management order under the Protection of Personal and Property Rights Act 1988, ss 30 or 31, and people aged less than 18. 
or liquidators. ${ }^{46}$ Trustee companies are the only corporate bodies that can act as receivers. ${ }^{47}$

In comparison, only bankrupts are uniformly unable to enter into possession since their right to do so vests in their assignee. ${ }^{48}$ The other groups traditionally lacking contractual capacity (minors ${ }^{49}$ and the mentally-impaired) are not uniformly barred. Although a mentally-impaired mortgagee's property rights can be transferred to a property manager, ${ }^{50}$ at law the mortgage is enforceable against the mortgagor. ${ }^{51}$ Similarly under the Minors' Contracts Act 1969, a minor's mortgage, and thus the right to enter into possession, is prima facie enforceable against the mortgagor. ${ }^{52}$ So while certain incompetent, biased, and untrustworthy people are wisely prohibited from managing land as "receivers", the law generally permits them to exercise similar powers if they don the mask of "mortgagees in possession", either when taking possession under their own mortgages or as employees hired to manage property on behalf of another mortgagee.

To correct this oversight, the list in section 5 of the Receiverships Act 1993 should be transplanted into the PLA, and the High Court should be empowered to ban people who repeatedly or seriously violate the duties of a mortgagee in possession from acting in that capacity.

\section{F How Might the Differences in Initiation Affect a Mortgagee's Choice of Remedy?}

A well-drafted mortgage will insulate a mortgagor's entitlement to possession and receivership from situation-specific facts. Nevertheless, a particular remedy may be impractical or impossible in a given situation. For instance, those holding mortgages personally or through closely-held companies could once appoint themselves as

46 As evidenced by a prohibition on them holding these positions issued by the court under the RA 1993, s 37(6), the Companies Act 1993, ss 286(5), 382, 383 or 385, or the repealed Companies Act 1955, ss 188A, 189, 189A, 199K, 199L, or 199N.

47 Trustee Companies Act 1967, s 7. The appointment of any other body corporate is a "nullity": Portman Building Society v Gallwey [1955] 1 All ER 227, 230 per Wynn-Parry J.

48 Insolvency Act 1964, s 42(2)(b).

49 Since 1 January 1971, a minor is someone aged less than twenty: Age of Majority Act 1970, s 4.

50 See the Protection of Personal and Property Rights Act 1988, by which the Family Court can appoint a manager over the property of anyone lacking the competence to manage their own affairs.

51 Although possibly not against the mentally-impaired mortgagee. See, for example, O'Conner $v$ Hart [1985] 1 NZLR 159 (PC); Imperial Loan Co v Stone [1892] 1 QB 599 (CA).

52 See generally J Burrows, J Finn and S Todd Law of Contract in New Zealand (Butterworths, Wellington, 1997) para 13.1, 441-447. 
receiver, ${ }^{53}$ but now must enter into possession instead. ${ }^{54}$ A lack of forethought or inexperienced drafting might lead to the omission of a receivership clause, thus excluding that remedy. In some cases, a mortgagee might suspect a disgruntled mortgagor will poison crops or commit arson, but will lack the evidence necessary to obtain the court's permission for early possession. ${ }^{55}$ By appointing a receiver they can immediately establish a presence on the land to discourage such acts. Another factor is the cost; receivership is cheaper as possession often requires a court order.

\section{SPECIFIC OBLIGATIONS}

Once a remedy is initiated various statutory obligations regulate the information flowing to the mortgagors. Their importance is reflected in the fines of up to $\$ 10,000$ levied upon their non-observance. These obligations' social value, plus the similar status of mortgagees in possession and receivers, suggests that they should be identically applied. Surprisingly, some are not.

\section{A Notice Obligations}

Both groups must give written notice of their possession or appointment to the mortgagor and public. ${ }^{56}$ The relevant registrar ${ }^{57}$ and Commissioner of Inland Revenue ${ }^{58}$ may also require notification.

Receivers alone must note their appointment on documents relating to the mortgaged property bearing the mortgagor's name. ${ }^{59}$ This informs third parties that the mortgagor is in financial difficulty, a sensible protection which should also be required of mortgagees in possession.

53 An example is provided by Mr Russell, whose exploits led to litigation in Re Tricorp Investments Ltd (1988) 4 NZCLC 64, 620 (HC), Downsview Nominees Ltd v First City Corporation [1993] 1 NZLR 513 (PC), and Downsivew Nominees Ltd v Official Assignee (1994) 7 NZCLC 260, 605.

54 Due to the RA 1993, ss 5(1)(b), 5(1)(c)(i), 5(1)(c)(ii), 5(1)(d(i), and 5(1)(d)(ii) .

55 PLA 1952, s 92(5).

56 PLA 1952, s 104DD(1); RA 1993, s 8(1).

57 PLA 1952, s 104DD(3); RA 1993, s 8(3). The relevant registrar may be the Companies Registrar, Registrar of Industrial and Provident Societies, Registrar of Incorporated Societies or the Registrar of Friendly Societies and Credit Unions: RA 1993, s 2 "Registrar".

58 Goods and Services Tax Act 1985, s 58(3). This is only if a taxable activity of the mortgagor is continued.

59 RA 1993, s 10. 


\section{B Accounting Obligations}

Both groups must keep income of the mortgaged property separate ${ }^{60}$ and keep ${ }^{61}$ accounting records that "correctly record and explain the receipts, expenditure, and other transactions relating to the [mortgaged] property". ${ }^{62}$ But as agents, receivers alone must observe the additional accounting standards imposed by general agency law. ${ }^{63}$

\section{Reporting Obligations}

Within two months of possession or appointment, both groups must prepare a report summarising the property's state of affairs. ${ }^{64}$ Similar reports are made within the two months following every successive six month period. ${ }^{65}$

Only receivers must separately calculate the amounts owed to preferential creditors. ${ }^{66}$ More importantly, only receivers must give details of past sales in every report; a mortgagee in possession's first report need only detail proposals for future sales. ${ }^{67}$ This apparent drafting oversight should be amended to reduce the likelihood of litigation over mortgagee sales. ${ }^{68}$

\section{Whistle-Blowing Obligations}

Both groups must notify the Companies Registrar of any suspected breaches by a corporate mortgagor's directors of the Companies Act 1955, Companies Act 1993, or Securities Act $1978 .{ }^{69}$ Only receivers must report further suspected offences against the Financial Reporting Act 1993 and Takeovers Act 1993. ${ }^{70}$

60 PLA 1952, s 104HH; RA 1993, s 21.

61 For at least six years after the termination of the possession or receivership: PLA 1952, s 104GG(2); RA 1993, s 22(2).

62 PLA 1952, s 104GG(1); RA 1993, s 22(1).

63 Smiths Ltd $v$ Middleton [1979] 3 All ER 842 (receiver liable for not elaborating on statutorily required abstracts).

64 PLA 1952, s 104II; RA 1993, s 23.

65 PLA 1952, s 104JJ; RA 1993, s 24.

66 RA 1993, s 23(2)(d).

67 Compare PLA 1952, s 104II(2)(b) with RA 1993, s 23(2)(b).

68 See NZLC R29, above n 16, Draft Property Law Act cl 134(4)(b), 115, which corrects this oversight.

69 PLA 1952, s104NN; RA 1993, s 28.

70 Inserted by the Receiverships Amendment Act 1994, s 4. 
The law imposes upon receivers alone the related duty of ensuring that a corporate mortgagor does not commit offences, for instance by not paying taxes. ${ }^{71}$

\section{E How Do the Differences in Specific Obligations Impact the Choice of Remedy?}

The very existence of these obligations, which may require expertise and time to discharge and are accompanied by sizeable fines, provides mortgagees with limited time or accounting skills good reason for choosing receivership. A further advantage is that only receivers can petition the court to relieve them of the need to comply with an obligation. ${ }^{72}$

This section has discussed tasks that must be performed. The next section investigates the powers that mortgagees in possession can opt to exercise.

\section{RIGHTS AND POWERS}

\section{A Sources}

The default powers of mortgagees in possession and receivers come from statute and the general law, but can be altered by the mortgage contract itself. ${ }^{73}$ Additional powers arise from the principle that, "when an express authority is given, there is an implied authority ... to do all acts which may be necessary for the purpose of effecting the object for which the express authority is given." ${ }^{74}$ The principle most usefully combines with a receiver's open-ended power to "manage the property in receivership". ${ }^{75}$

Rights and powers can be categorised according to whether their existence makes possession or receivership the more attractive option.

71 Re John Willmet (Ashford) Ltd [1979] 2 All ER 615, where a receiver was required to pay the mortgagor company's value-added tax.

72 RA 1993, s 37(4)(a).

73 RA 1993, s 14(2).

74 Pole v Leask (1860) 28 Beav 562, 575 per Sir John Romilly. Note that the principle seemed limited to extending "express authorities" given orally, but later cases did not draw this distinction. See also Inglis Electrics Pty Ltd $v$ Healing (Sales) Pty Ltd [1965] NSWR 1652, 1656 per Asprey J (NSW:SC); Australian Boot Trade Employees' Federation v Whybrow \& Co (1910) 11 CLR 311, 337 per Isaacs J (HCA).

75 RA 1993, s 14(2)(c). For instance, this express power conveys an implied power to "hive-down": Blanchard and Gedye, above n 39, para 10.07, 232. 


\section{B Rights and Powers Which Should not Affect a Mortgagee's Choice of Remedy}

\section{List of shared powers}

In relation to existing leases, mortgagees in possession stand, "as though the reversion of the land were for the time being vested at law in the mortgagee" 76 and receivers are empowered to "demand and recover, by action or otherwise, income of the property in receivership." 77 Thus both groups may demand rent, distrain against a non-residential ${ }^{78}$ tenant's possessions, ${ }^{79}$ or sue a tenant's guarantors. They can also grant new tenancies, although a mortgagee in possession is limited to granting leases of seven years or less. ${ }^{80}$

Both groups can collect income by logging trees ${ }^{81}$ or harvesting crops, ${ }^{82}$ although mortgagees in possession can claim only those crops harvested after possession was taken. ${ }^{83}$ There is no power to embark on risky ventures. ${ }^{84}$

Both groups may adopt the mortgagor's existing contracts. Adoption in this sense requires more than acquiescence: "a novation or renegotiation is required. ${ }^{85}$ If not adopted, the contract remains in force between the mortgagor and third party unless repudiated. ${ }^{86}$

Receivers can enter new contracts concerning the mortgaged property if, "necessary or incidental to the exercise of [their other] powers". ${ }^{87}$ They can also use a company

76 PLA 1952, s 91(11).

77 RA 1993, s 14(2)(a).

78 Note PLA 1952, s 107A(a): "No person shall be entitled to distrain for any rent due under any lease of a dwellinghouse."

79 LTA 1952, s 107. Provided the rent is twenty-one days late and seven further days have passed since payment was requested. See further the Distress and Replevin Act 1908.

80 PLA 1952, s 91(1).

81 PLA 1952, s 95.

82 See Corbett v Agnew [1930] NZLR 1033 (SC); Bagnall v Villar (1879) 12 Ch D 812.

83 Re Phillips (1880) 16 Ch D 104 (CA).

84 Hughes $v$ Williams (1806) 12 Ves Jun 494, where a mortgagee in possession could not claim from the mortgagor the costs of opening a slate quarry.

85 The Laws of New Zealand (Butterworths, Wellington, 1996), vol 22, Receivers, para 1, 3 ["LNZ Receivers"], para 43, 50. See also Greenwood v Martins Bank Ltd [1933] AC 51, 57 per Lord Tomlin (HL), stating that in contract, "adoption requires valuable consideration"; Re Diesels $\mathcal{E}$ Components Pty Ltd (1985) 2 Qd R 456, 459 per McPherson J.

86 See below subsection V C 2: Power to Repudiate Existing Contracts.

87 RA 1993, s 13(1). 
mortgagor's seal ${ }^{88}$ and their power of management implies a right to borrow and grant security in the mortgagor's name. ${ }^{89} \mathrm{~A}$ mortgagee in possession's freedom of contract means they too can enter such contracts in their own name.

Importantly, both groups can enter self-interested transactions. Keech $v$ Sandford ${ }^{90}$ states that fiduciaries cannot use their position for self-profit, ${ }^{91}$ but mortgagees are not trustees. ${ }^{92}$ A good illustration is White $v$ City of London Brewery, ${ }^{93}$ where a mortgagee in possession leased the mortgaged pub subject to the purchaser agreeing to buy beer exclusively from the mortgagee, who was a brewer. The resulting profits were held to belong to the mortgagee's business, not to the mortgagor's hereditaments, and so the mortgagee could keep them. ${ }^{94}$ The mortgagor could only recover the extra rent that would have been made had the property been let without the restrictive covenant.

Additionally, mortgagees can sell mortgaged property to relatives or companies in which they have an interest provided they act in good faith and take reasonable care to get a proper price. ${ }^{95}$ They cannot, however, sell to themselves. ${ }^{96}$

Receivers, despite their "agent" status, do not owe a full range of fiduciary duties ${ }^{97}$ and can also enter self-interested transactions provided they observe their duties, fully disclose their interest, and obtain the mortgagor's informed consent. ${ }^{98}$

88 RA 1993, s 13(4). Only companies registered under the Companies Act 1955 must stamp their deeds with their company seal: Companies Act 1993, s 180(1A).

89 This is especially so when the mortgagor is a company, since receivers inherit the directors' implied duty to borrow and grant security: General Auction Estate and Monetary Company $v$ Smith [1891] 3 Ch 432; Re Patent File Company (1870) 6 Ch App 83.

90 Keech $v$ Sandford (1726) 2 Eq Cas Abr 741.

91 See also Boardman v Phipps [1966] 3 All ER 721 (HL) per Lords Cohen, Hodson and Guest (Lord Upjohn and Viscound Dilhorne dissenting), extending this to information gained as trustee.

92 Nash v Eads (1880) 25 Sol J 95; Warner v Jacob (1882) 20 Ch D 220; Matai Industries Ltd v Jensen [1989] 1 NZLR 525 (HC).

93 White v City of London Brewery Co (1889) 42 ChD 237.

94 White v City of London Brewery Co (1889) 42 ChD 237, 245 per Cotton LJ.

95 For examples of a mortgagee failing to meet these requirements, see Australian and New Zealand Banking Group Ltd v Bangdilly Patoral Co Pty Ltd (1978) 52 ALJR 529 (HCA) and Tse Kwong Lam v Wong Chit Sen [1983] All ER 54 (PC).

96 Farrar v Farrars Ltd (1888) 40 Ch D 395, 409 per Lindley LJ: "a sale by a person to himself is no sale at all".

97 A receiver's agency is "clearly of a special kind": Re Tricorp Investments Ltd (1988) 4 NZCLC 64,620, 64,624 per Thorp J (HC). 
Both groups can repair and maintain the mortgaged property. ${ }^{99}$ Receivers are undoubtedly permitted to insure the property, 100 and mortgagees in possession to protect the property from vandals. ${ }^{101}$

Both groups can sue third parties in contract or tort. ${ }^{102}$ Receivers can sue in the mortgagor's name ${ }^{103}$ without the mortgagor's consent, ${ }^{104}$ although they may have to provide security for costs. ${ }^{105}$ This power is implied from the power to "get in" the mortgagor's assets, as without it that power might be illusory. ${ }^{106}$

Finally, both groups can access all "books, documents and information" in the mortgagor's possession relating to the mortgaged property. ${ }^{107}$

98 See generally Blanchard and Gedye, above n 39, para 10.05, 230-231; LNZ Receivers, above n 85, para 34, 42: "it would appear that there is no inflexible rule preventing a receiver from selling the property to the [mortgagee] or to a party in which the receiver has an interest."

99 RA 1993, s 14(2)(e). Compare the position at common law: White $v$ Metcalf [1903] 2 Ch 567; Visbord $v$ Federal Commissioner of Taxation (1943) 68 CLR 354, 382 (HCA). For mortgagees in possession, maintenance of the property out of received income is actually a duty. See Richards $v$ Morgan (1753) 4 Y\&C Ex 570; Leech v National Bank of New Zealand [1996] 3 NZLR 707, 713 per Paterson J (HC).

100 RA 1993, s 14(2)(d).

101 See Western Bank Ltd v Schindler (1976) 2 All ER 393, 396 per Buckley LJ (CA).

102 Trustbank Canterbury Ltd v Lockwood Buildings Ltd [1994] 1 NZLR 666, 674-677 per Holland J (HC), stating that a mortgagee in possession can sue for trespass and conversion (affirmed as Lockwood Buildings $v$ Trust Bank [1995] 1 NZLR 22 (CA)). Inglis Electrix Pty Ltd v Healing (Sales) Pty Ltd [1965] NSWR 1652 (NSW:SC), in which a receiver was allowed to sue for trespass and conversion.

103 Generally not in their own name because no property, including causes of action, vests in them upon appointment: Robertson v Oskar [1984] (1983) 8 ACLR 570 (HCA); Re Sartoris's Estate [1892] 1 Ch 11, 22 per Lindley J (CA). Examples of when receivers can bring their own actions are discussed in Re Sacker (1888) 22 QBD 179, 185 per Fry LJ.

$104 \mathrm{M}$ Wheeler and Co Ltd $v$ Warren [1928] 1 Ch 840 (CA).

105 High Court Rules, R 60; District Court Rules 1992, R 61. See Attorney-General v Bell-Booth Group Ltd (1986) 3 NZCLC 99, 774 (CA) for principles of requesting security for costs. For an example of costs being awarded against a non-party receiver, see Knight v F P Special Assets Ltd (1992) 174 CLR 178 (HCA).

106 M Wheeler \& Co Ltd $v$ Warren [1928] 1 Ch 840, 846 per Lawrence LJ (CA).

107 PLA 1952, s 104FF; RA 1993, s 12. See also Richmond Equities Ltd v Interfauna Trading Co (NZ) Ltd (1988) 4 NZCLC 64, 606 (HC) where this right was extended to documents containing confidentiality clauses. 


\section{Freedom from interference}

Both groups enjoy general freedom from interference. Mortgagors cannot impeach the decisions of mortgagees in possession or receivers just because they, or even the court, would have acted differently. ${ }^{108}$ Although mortgagors are legally the receivers' principals, ${ }^{109}$ receivers "[are] not to receive directions from [mortgagors] but to give directions." 110

Some cases suggest that mortgagors can use their residual powers ${ }^{111}$ to contradict a mortgagee in possession or receiver's wishes. In Newhart Developments Ltd $v$ Cooperative Commercial Bank Limited ${ }^{112}$ a company's directors were allowed to sue the debentureholder that put them into receivership even though the receiver did not consent. ${ }^{113}$ In $R e$ Reprographic Exports ${ }^{114}$ a mortgagor's directors were able to oppose a winding-up order brought by a receiver. But later judgments have cast doubt on the correctness of Newhart Developments, suggesting that a division in power between mortgagee/receiver and mortgagor cannot exist, and that the mortgagor cannot manipulate the mortgaged property at all. ${ }^{115}$

Third parties interfering with a mortgagee in possession or receiver can be restrained by injunction. ${ }^{116}$ The main exceptions are prior mortgagees, who by taking possession or appointing a receiver themselves can suspend the tenure of a mortgagee in possession or

108 "The choice between alternative courses is for the secured creditor and for them alone": Re Neon Signs (Australasia) Ltd [1965] VR 125, 127 per Adam J (Vic:SC).

109 Gomba Holdings UK Ltd v Minories Finance Ltd [1988] 1 WLR 1231, 1233 per Fox LJ (CA).

110 Meigh $v$ Wickenden [1942] 2 KB 160, 166 per Viscount Caldecote CJ, referring to a receiver's relationship with a company mortgagor's directors.

111 A company mortgagor's Board retains all powers not delegated to the receiver. See MacDuff's Ltd $v$ National Bank of NZ Ltd [1939] GLR 539, 540 per Myers CJ (SC); Brooklands Motor Co Ltd v Bridge Wholesale Acceptance Corporation (Australia) Ltd [1994] MCLR 193; Hawkesbury Development Co Ltd $v$ Landmark Finance Pty Ltd [1969] 2 NSWR 782, 790 per Street J (NSW:SC): "A valid receivership and management will ordinarily supersede, but not destroy, the company's own organs through which it conducts its affairs."

112 Newhart Developments Ltd v Cooperative Commercial Bank Limited [1978] 2 All ER 896 (CA).

113 The New Zealand Court of Appeal has subsequently held that a mortgagor must always retain the right to pursue any dispute with the mortgagee over the mortgage agreement: Paramount Acceptance Co Ltd $v$ Souster [1981] 2 NZLR 38 (CA).

114 Re Reprographic Exports (1978) 122 Sol J 400.

115 See Tudor Grange Holdings Ltd v Citibank NA [1991] 4 All ER 1, 10-11 per Browne-Wilkinson VC.

116 See, for example, Bayley $v$ Went (1884) 51 LT 764, where a mortgagor distrained against a tenant after the receiver's appointment. 
receiver operating under a junior security, ${ }^{117}$ and the courts, which are statutorily empowered to terminate or limit possession or receivership if circumstances no longer justify its continuation. ${ }^{118}$

\section{Rights and Powers Which Favour Entry into Possession}

\section{Power to carry on business}

An important line of authority allows mortgagees in possession to run the business of a mortgagor notwithstanding that their security is a mortgage over land and not a company debenture. In County of Gloucester Bank $v$ Rudry Merthyr Steam and House Coal Colliery Company, 119 the defendant mortgaged their "colliery", which Lord Halsbury thought meant more than just the coal-mine and buildings: "What does ['colliery'] mean but that industrial occupation which we compendiously call a colliery?"120 The mortgage was found to pass the right to mine and sell coal. Lindley LJ added: "Bear in mind that if [the mortgagee does] nothing the mine will be swamped with water, and the property will not be ... what it was intended to be, namely, a security for repayment of their money." ${ }^{121}$ In Gay $v$ Johnson ${ }^{122}$ a mortgage over land from which a hotel operated was said to prima facie include the licence to operate the hotel, despite the mortgage containing no words to that effect. ${ }^{123}$

In principle, receivers should possess a similar power. However, in Te Runanganui o Ngati Kahungunu Inc $v$ Scott, a court-appointed receiver was to be given "the powers in s14(2) of the Receiverships Act 1993, and the power to carry on the business of the society." 124 This juxtaposition suggests that a receiver's statutory power of management does not empower them to run a business. The New Zealand Law Commission also

117 See Blanchard and Gedye, above n 39, para 4.22, 89.

118 PLA 1952, s 104PP; RA 1993, s 35.

119 County of Gloucester Bank v Rudry Merthyr Steam and House Coal Colliery Company [1895] 1 Ch 629 (CA).

120 County of Gloucester Bank v Rudry Merthyr Steam and House Coal Colliery Company [1895] 1 Ch 629, 634 (CA).

121 County of Gloucester Bank v Rudry Merthyr Steam and House Coal Colliery Company [1895] 1 Ch 629, 638 (CA).

122 Gay v Johnson (1937) 37 SR (NSW) 454.

123 For examples of this power being expressed in the mortgagee, see Philp Trustee Co Ltd $v$ Ironside Investments Pty Ltd [1984] 2 Qd R 16 (Qld:SC); Atkins v Mercantile Credits Ltd (1986) 10 ACLR 153 (NSW:SC).

124 Te Runanganui o Ngati Kahungunu Inc v Scott [1995] 1 NZLR 250, 251 per Neazor J (HC). 
treated, "manage any of the property in receivership" and, "carry on any associated business", as separate powers, ${ }^{125}$ with the latter power eventually dropped. It thus appears that the power to run a business will not readily be implied from a receiver's power of management.

\section{Power to repudiate existing contracts}

Generally both groups can cancel the mortgagor's existing contracts with third parties, with the third party's claim for damages ranking behind the mortgagee's claim. ${ }^{126}$ However, if the third party could have claimed specific performance or an equitable injunction against the mortgagor, a receiver, as the mortgagor's agent, is bound by that equity, preventing repudiation. ${ }^{127}$ Thus in Schering Pty Ltd $v$ Forrest Pharmaceutical Co Pty $L t d^{128}$ a receiver had to honour a pre-receivership contract granting the plaintiff exclusive purchasing rights because the plaintiff had incurred large losses marketing the mortgagor's product. ${ }^{129}$

Mortgagees in possession are not affected by this rule and can repudiate existing contracts more freely. ${ }^{130}$ However, their right to repudiate residential tenancies is limited by statute. ${ }^{131}$

\section{Right to ignore a corporate mortgagor's constitution}

Mortgagees in possession are not bound by the dictates of a corporate mortgagor's constitution. However, as receivers are theoretically delegated their powers by the mortgagor, any limits on a corporate mortgagor's powers, such as those enshrined in its constitution, should constrain the receiver. ${ }^{132}$

125 NZLC R9, above n 29, Draft Property Law Amendment Act, cl 104AJ, 398.

126 Quik Bake Products Ltd $v$ New Zealand Baking Trade Employees Industrial Union of Workers (1990) 5 NZCLC 66,701 (CA).

127 S Dukeson "Company Pot-Pourri" [1989] NZLJ 141, 142. This will often be so if the contract is for the sale of unique goods: Butler v Countrywide Finance Ltd [1993] 3 NZLR 623 (HC).

128 Schering Pty Ltd $v$ Forrest Pharmaceutical Co Pty Ltd [1982] 1 NSWLR 286 (NSW:SC).

129 Compare Airlines Airspares Ltd v Handley Page Ltd [1970] 1 All ER 29, where a similar application failed as the plaintiff could not, in this case, have claimed specific performance against the mortgagor.

130 See below subsection VII B: Liabilities to Third Parties in Tort.

131 Residential Tenancies Act 1986, s 58.

132 LNZ Receivers, above n 85, para 32, 39. 
An authority to the contrary is Re Emmadart $L t d,{ }^{133}$ where a receiver brought a winding-up application against a mortgagor company. The mortgagor could not have brought this application without a shareholders' special resolution but Brightman J allowed the receiver's application, stating, "[t]he authority of a receiver is not ... coterminous with the authority of the board of directors."134

Re Emmadart is usually cited for the proposition that the power to apply for windingup is incidental to the power to protect and preserve a mortgagor's assets. ${ }^{135}$ Rarely, if ever, has the case been used to support the far more controversial claim that receivers can ignore mortgagors' constitutions. Indeed, since mortgagees can examine mortgagors' constitutions before lending money, their appointed receivers should be so constrained.

\section{Right to vacant possession}

Mortgagees in possession can require the removal of any chattels from the land ${ }^{136}$ and after taking physical possession can treat the mortgagor's chattels as those of a trespasser, with no obligation to care for them. ${ }^{137}$

\section{Rights and Powers Which Favour Receivership}

\section{Right to remuneration}

Receivers are usually paid by the mortgagee, but as agents of the mortgagor can also pay themselves directly from the mortgaged assets. This right is lost through unacceptable conduct, ${ }^{138}$ and any remuneration can be judicially scrutinised. ${ }^{139}$

133 In Re Emmadart Ltd [1979] 1 All ER 599.

134 In Re Emmadart Ltd [1979] 1 All ER 599, 605.

135 See, for example, LNZ Receivers, above n 85, para 38, 46; Blanchard and Gedye, above n 39, para 10.30, 253.

136 Norwich Union Insurance Society v Preston [1957] 2 All ER 428.

137 Jones v Foley [1891] 1 QB 730, 732 per Daly J. See generally ELG Tyler (ed) Fisher \& Lightwood's Law of Mortgage (10 ed, Butterworths, London, 1988) 351-352.

138 See, for example, Andrews v Ramsey \& Co [1903] 2 KB 635 (agent took a secret commission); Greenwood v Harvey (1965) 83 WN Pt 2 NSW 374 (NSW:SC) (receiver colluded with purchaser of mortgagor's assets); New Zealand Farmers' Cooperative Distributing Co Ltd v National Mortgage and Agency Co of New Zealand Ltd [1961] NZLR 969 (SC) (agent failed to exhibit reasonable knowledge and skill).

139 A wide range of people can initiate a remuneration review: RA 1993, s 34(2). For an example of remuneration fixing see Prior $v$ Bagster (1887) 57 LT 760, where the receiver was granted 5\% of the recovered assets' value. 
Mortgagees in possession and their agents have no right to remuneration for the time spent managing the mortgagor's property. ${ }^{140}$ Equity once voided contractual provisions to the contrary because, ${ }^{141}$ having chosen not to appoint a receiver, a mortgagee could not charge a receiver's commission. ${ }^{142}$ Today the validity of such an agreement would depend on whether it was a permissible collateral advantage. ${ }^{143}$

\section{Power to sell mortgaged property}

The power of sale is implied into all mortgages unless negatived, ${ }^{144}$ and granted to all receivers by common law. ${ }^{145}$ Importantly, mortgagees cannot buy at their own sale but can buy from a receiver's sale. ${ }^{146}$

\section{Right to provision of essential services}

The suppliers of water, electricity, gas, or telecommunications ${ }^{147}$ cannot halt their supply to property in receivership simply because the mortgagor has outstanding debts. ${ }^{148}$ Mortgagees in possession are not similarly protected.

\section{Right to seek to judicial guidance}

Receivers can apply to the High Court for directions on how to exercise their powers ${ }^{149}$ and will generally be immune from liability for any act or omission reliant on such

140 Bonithon v Hockmore (1685) 1 Vern 316; Chambers v Goldwin (1804) 9 Ves 254.

141 Comyns $v$ Comyns (1871) IR 5 Eq 583, where a term entitling a mortgagee in possession to 100 pounds a year was disallowed. See also French $v$ Baron (1889) 2 Atk 120.

142 Carew v Johnston (1805) 2 Sch \& Lef 280, 301 per Lord Redesdale.

143 See Biggs $v$ Hoddinot [1898] 2 Ch 307 (CA); Young, above n 31, para 26.34, 445, stating that mortgagees in possession can recover charges for their services under an "agreement with the mortgagor".

144 PLA 1952, s 78, and Fourth Schedule cl 8.

145 In re Manchester and Milford Railway Co (1880) 14 Ch D 645, 653 per Jessel MR.

146 Although such a sale will be carefully scrutinised: Blanchard and Gedye, above n 39, para 10.12, p237.

147 RA 1993, s 40(1).

148 RA 1993, s 40(3).

149 RA 1993, s 34(1). 
directions. ${ }^{150}$ The Court will advise only upon matters of law, not on factual matters of commercial judgment. ${ }^{151}$

\section{E How Do the Differences in Rights and Powers Affect the Choice of Remedy?}

Possession has the obvious advantage of allowing mortgagees to exert direct control over the land's management. American Express $v$ Hurley ${ }^{152}$ shows that receivership generally requires mortgagees to adopt a "hands-off" approach. ${ }^{153}$

Possession may be advantageous if a mortgagee wishes to run a pre-existing business from the land, turn out the mortgagor (vacant land fetches more than adversely occupied land), escape contractual obligations which would bind a receiver, or avoid restrictions in a corporate mortgagor's constitution.

The disadvantages of possession are that mortgagees are less able to bill mortgagors for the time spent in possession, and cannot insulate themselves from liability by seeking judicial guidance on legally questionable decisions.

Neither group enjoys complete freedom in choosing when and how to exercise these powers. Primarily, their choices are limited by the need to observe the equitable and statutory duties discussed below.

\section{DUTIES}

This article proposes that a "fundamental duty" exists which applies except where replaced or supplemented with a more stringent duty. The fundamental duty for mortgagees in possession is the equitable duty of good faith as described in Downsview Nominees $v$ First City Corporation ${ }^{154}$. The fundamental duty for receivers is the more onerous, tiered duty prescribed by section 18 of the Receiverships Act 1993.

These duties are enforced primarily by courts awarding damages or issuing preventative injunctions. ${ }^{155}$ Receivers are subject to additional controls: numerous

\footnotetext{
150 RA 1993, s 37(6).

151 Re Blastclean Services Ltd (1985) 2 NZCLC 99,282, 99,285 per Barker J (HC).

152 American Express International Banking Corporation v Hurley [1985] 3 All ER 564.

153 See below sub-section V F 3: Direct control of a receiver by the appointing mortgagee.

154 Downsview Nominees Ltd v First City Corporation [1993] 1 NZLR 513 (PC) [Downsview].

155 For a discussion of the possible grounds for awarding an injunction, see New Zealand Commentary on Halsbury's Laws of England (4 ed, Butterworths, Wellington, 1989) binder E, Mortgage, para C725, 56; George Hinde and Donald McMorland Land Law in New Zealand (1 ed, Butterworths, Wellington, 1997), para 8.132, 749-752.
} 
interested parties can petition the High Court to order them to comply with their duties, ${ }^{156}$ they can be removed if they breach such an order ${ }^{157}$ or otherwise misconduct themselves, ${ }^{158}$ and their conduct is scrutinised during a corporate mortgagor's liquidation. ${ }^{159}$ The New Zealand Law Commission's suggestion that similar judicial controls apply to mortgagees in possession was not taken up. ${ }^{160}$

\section{A The Fundamental Equitable Duty of Mortgagees}

\section{The duty defined}

The New Zealand Court of Appeal in Downsview held that mortgagees and receivers owed a duty in negligence to act with reasonable care in all their actions. ${ }^{161}$ This conclusion was reached after applying the two-stage "Anns test" (used to establish new categories of negligence liability) ${ }^{162}$ and supported with reference to Cuckmere Brick Co Ltd $v$ Mutual Finance $L t d^{163}$. Equity was rejected as the duty's source: "if there were any duties on the part of [the appointor] and [the receiver] ... they would have to based in negligence." 164

On appeal, the Privy Council, "considerably troubled by the approach of the Courts below", 165 unequivocally stated that the duties of mortgagees and receivers lay in equity alone. ${ }^{166}$ Their general duty, owed to the mortgagor and subsequent encumbrancers ${ }^{167}$

156 RA 1993, s 37

157 RA 1993, s 37(5).

158 This can be done under the court's equitable jurisdiction: Re Neon Signs (Australasia) Ltd [1965] VR 125, 127 per Adams J (Vic:SC).

159 Companies Act 1993, s 301. See generally Blanchard and Gedye, above n 39, para 11.41, 316-317.

160 New Zealand Law Commission "The PLA 1952: A Discussion Paper" (Law Commission, Wellington, 1991) Preliminary Paper No 16, para 309, 101.

161 First City Corporation v Downsview Nominees Ltd [1990] 3 NZLR 265 (CA).

162 Anns $v$ London Merton-Borough Council [1978] AC 728, 751-752 per Lord Wilberforce (HL). English courts have subsequently retreated from this test: Caparo Industries plc v Dickman [1990] 2 AC 605, 617 per Lord Bridge, 649 per Lord Oliver; Murphy v Brentwood District Council [1991] 1 AC 398 (HL).

163 Cuckmere Brick Co Ltd v Mutual Finance Ltd [1971] 1 Ch 949 (CA) [Cuckmere Brick].

164 First City Corporation v Downsview Nominees Ltd [1990] 3 NZLR 265, 272 per Richardson J (CA).

165 Downsview Nominees Ltd v First City Corporation [1993] 1 NZLR 513, 521 per Lord Templeman (PC).

166 Downsview Nominees Ltd v First City Corporation [1993] 1 NZLR 513, 526 (PC).

167 But see Andrew Hogan "Receivers Revisited" (1996) 17 Company Lawyer 226, 229 suggesting that the duty owed to subsequent encumbrancers should be stricter than good faith. 
(and according to other cases, guarantors and suretors) ${ }^{168}$ was to act in good faith for the purpose of obtaining repayment, a less onerous duty than one based in negligence.

"Good faith" is a, "protean term having longstanding usage in a variety of ... contexts". ${ }^{169}$ In the Downsview context, this duty is breached only by intentional behaviour amounting to "some dishonesty, improper motive or ... bad faith", 170 although recklessness might also suffice. ${ }^{171}$

\section{Why was a duty in negligence rejected?}

Lord Templeman, who delivered the Council's opinion, had previously shown disdain for negligence's rapid infestation of the law of obligations: "since Anns v Merton London Borough Council ... put the floodgates on the jar, a fashionable plaintiff alleges negligence. The pleading assumes we are all neighbours now, Pharisees and Samaritans alike ... and that for every mischance in an accident-prone world someone solvent must be liable in damages." 172 And later; "the [Hong Kong] Court of Appeal sought to find a duty in the tort of negligence but the tort of negligence has not yet subsumed all torts and does not supplant the principles of equity". ${ }^{173}$ This suggests that Downsview reflected a policy of restricting negligence rather than an open-minded consideration of the appropriate standard of care. Negligence liability in the sphere of mortgages would have also allowed recovery for pure economic loss, an unfavoured outcome. ${ }^{174}$

168 See China \& South Sea Bank Ltd v Tan Goon Sin [1989] 3 All ER 839 (PC); Ent v McVeigh (4 October 1996) unreported, Tasmanian Supreme Court, A61/1996, per Slicer J, refusing an application for summary judgment that the duty was not owed to guarantors. But compare Clyde Industries Ltd v Dittes (5 June 1992) unreported, New South Wales Supreme Court, per Cole J) which recognised some complications arising from this extension.

169 Secretary, Department of Education, Employment, Training and Youth Affairs v Prince (21 November 1997) unreported, NSW Federal Court, per Finn J, 1997 AUST FEDCT LEXIS 1072).

170 Medforth $v$ Blake [1999] 3 All ER 87 per Sir Richard Scott VC. See also Kennedy $v$ De Trafford [1896] 1 Ch 762, 772 per Lindley J (CA) [affirmed [1897] AC 180 (HL)] stating that only the fraudulent, wilful or reckless sacrifice of the mortgagor's interests would amount to a breach of the duty of good faith; Goldcel Nominees Pty Ltd v Network Finance Ltd [1983] 2 VR 257, 261 per Murphy J (Vic:SC): "'In good faith' must, in my opinion, import a subjective element of honesty, fairness and lack of fraud or collusion."

171 Moritzson Properties Ltd v McLachlan [1994] 3 NZLR 250 (HC); Barns v Queensland National Bank Ltd (1906) 3 CLR 925 (HCA).

172 CBS Songs Ltd v Amstrad Consumer Electronics Plc [1988] 1 AC 1013, 1059 (HL).

173 China and South Sea Bank v Tan Soon Gin [1989] 3 All ER 839, 841 (PC).

174 Murphy v Brentwood District Council [1991] 1 AC 398 (HL). 
Lord Templeman's more reasoned basis for rejecting negligence-based duties was that they would require substantial regard to be given to the interests of the mortgagor and third parties, clashing with a mortgagee or receiver's primary obligation to repay the mortgagee's loan. This reasoning came from Re B Johnson $\mathcal{E}$ Co (Builders) Ltd, where receivers were said to owe a primary duty to their appointors which altered the emphasis to be placed on various parties' interests. ${ }^{175}$ Similarly in Kennedy $v$ de Trafford, "a mortgagee is not a trustee ... his right is to look after himself first", 176 and in Newhart Developments Ltd v Co-operative Commercial Bank Ltd, "[t]he receiver is entitled to ignore the claims of anybody outside the debenture holders." 177 While this latter statement no longer represents New Zealand law, ${ }^{178}$ it illustrates the traditional tolerance for the partiality of mortgagees and receivers which negligence liability undermines.

In theory, receivers focused on rescuing a mortgagor's business, rather than repaying the mortgagee, might be less entitled to discount other parties' interests. ${ }^{179}$ But in New Zealand, where receivers are not "white knight[s]"180 and must pursue their appointor's interests, this point is moot.

In New Zealand, the fundamental duty of good faith applied to both mortgagees and receivers from November $1992^{181}$ until July 1994, when the Receiverships Act 1993 came into effect.

\section{B The Fundamental Statutory Duty of Receivers}

Receivers must act in good faith ${ }^{182}$ and in their appointor's best interests. ${ }^{183}$ Essentially this encapsulates the Downsview decision. However, unlike mortgagees, receivers have a

175 In Re B Johnson E Co (Builders) Ltd [1955] Ch 634, 661-662 per Jenkins LJ (CA).

176 Kennedy $v$ de Trafford [1896] 1 Ch 762, 772 per Lindley J (CA) (affirmed [1897] AC 180 (HL)).

177 Newhart Developments Ltd v Co-operative Commercial Bank Ltd [1978] 2 All ER 896, 900 per Shaw J (CA).

178 See the RA 1993, s 18(3).

179 See Andrew Hogan "Receivers Revisited" (1996) 17 Company Lawyer 226, 230, criticising the equation of the duties of mortgagee and receiver as "ludicrous". For a detailed discussion of a receiver's potential "rescue" function in England see Gabriel Moss "Comparative Bankruptcy Cultures: Rescue of Liquidation? Comparison of Trends in National Law - England" (1997) 23 Brooklyn J Intl L 115.

180 First City Corporation v Downsview Nominees Ltd [1990] 3 NZLR 265, 275 per Richardson J (CA).

181 The date of the Downsview decision.

182 RA 1993, s 18(1).

183 RA 1993, s 18(2). 
secondary duty to reasonably regard the interests of the mortgagor, persons claiming through the mortgagor, and the mortgagor's unsecured creditors and suretors. ${ }^{184}$ This duty has been described as a "marked departure" from Downsview. ${ }^{185}$ It perpetuates the fundamental inconsistency of owing duties of care to both mortgagee and mortgagor. ${ }^{186}$

As to what level of "regard" is "reasonable", a principle eluded to in Hodson $v$ Deans states that more "regard" may be necessary when there is a "real or substantial possibility, rather than a probability", 187 of assets being left over after the mortgagee's loan is repaid. ${ }^{188}$

The exceptions and qualifications to these fundamental duties are now discussed.

\section{A Mortgagee's General Duty Under the Credit Contracts Act 1981}

If mortgagees, including those in possession, exercise their powers in an "oppressive" manner ${ }^{189}$ the courts have a wide remedial discretion and can direct mortgagees, "to do or refrain from doing in relation to any other party any act or thing."190 Allegations of oppressive conduct can be made in any court proceeding. ${ }^{191}$

Although mortgagees, unlike receivers, must be mindful of this statutory complement to their equitable duties, the potential for overturning a mortgagee's desired course of conduct is limited because if the mortgage's terms are not oppressive on their face, then "the exercise of the legal rights given to the mortgagee under that contract will not normally be held to be oppressive."192

\footnotetext{
184 RA 1993, s 18(3).

185 Andrew Beck and Andrew Borrowdale Guidebook to New Zealand Companies and Securities Legislation (6 ed, CCH New Zealand Ltd, Auckland) para 1313, 380.

186 A McRae "Duties of a Receiver" (1994) 73 Accountants' J 54.

187 Hodson v Deans (1903) 2 Ch 647, 652 per Joyce J, "[A mortgagee] is under certain obligations to the mortgagor, especially where the security is ample" [emphasis added].

188 See also Sewell v Agricultural Bank of Western Australia (1930) 44 CLR 104, 110 (HCA).

189 Credit Contracts Act 1981, s 10(b). "Oppressive" means "oppressive, harsh, unjustly burdensome, unconscionable, or in contravention of reasonable standards of commercial practice": Credit Contracts Act 1981, s 9.

190 Credit Contracts Act 1981, s 14(1)(f).

191 Credit Contracts Act 1981, s 10.

192 Young, above n31, para 23.21, 385. But this arguably contradicts the wording of the Credits Contracts Act 1981, s 10(b).
} 


\section{A Mortgagee's Duty Upon Entering into Possession}

Centuries ago, mortgagees' legal ownership of mortgaged property, plus mortgagors' equitable interest (their equity of redemption), led to the conclusion that mortgagees held mortgaged property on trust. ${ }^{193}$ As trustees, and because equity considered mortgages to be no more than a device to secure repayment, mortgagees in possession were required to diligently pursue such repayment, ${ }^{194}$ and were liable for any mismanagement reducing the level of income available to repay their loan. Thus mortgagees in possession had to account on the footing of wilful default, delivering to those interested in the equity of redemption ${ }^{195}$ income derived from the land plus money representing what should have been derived but for their "wilful default".

One of the earliest reported mortgagee possession cases reads, "mortgagee shall not account for more than he actually receives, unless where he has been guilty of a wilful default."196 These early cases offered little on the meaning of "wilful default", although fraud and bad faith were obviously included. ${ }^{197}$ Later, in Hughes $v$ Williams, "wilful default" was said to include "plain, obvious and gross negligence". ${ }^{198}$ Arguably then, the duty to avoid wilful default imposes a standard of care between "good faith" and "negligence" standards.

Examples of wilful default include rejecting a satisfactory tenant willing to pay more than the rent eventually received, ${ }^{199}$ and letting premises subject to a covenant which reduces the rent. ${ }^{200}$ However, it is not wilful default to accept reduced rent if the lowerpaying tenant is more credit-worthy, or if accepting a new, higher-paying tenant would erase the mortgagee's right to recover the current tenant's rent in arrears. ${ }^{201}$ Nor does a

193 Peter Devonshire "The Mortgagee's Power of Sale: A Case for the Equitable Standard of Good Faith" (1995) 46 NILQ 182, 183.

194 Lord Kensington v Bouverie (1855) 7 De GM\&G 134, 157 per Turner LJ.

195 Namely the mortgagor plus any subsequent encumbrancers of which the mortgagee was aware: Parker v Calcraft (1821) 6 Madd 11.

196 Anon (1682) 1 Vern 45. Other early cases include Duke of Bucks v Gayer (1684) 1 Vern 258; Coppring $v$ Cook (1684) 1 Vern 270.

197 Interestingly, Anonymous (1675) 1 Chan Cas 258 suggested that only fraud would trigger liability.

198 Hughes $v$ Williams (1806) 12 Ves Jun 494, 494 per Lord Erskine LC. See also Wragg v Denham (1836) 2 Y\&C Ex 117, 122 per Alderson B.

199 Anon (1682) 1 Vern 45.

200 White $v$ City of London Brewery Co (1889) 42 ChD 237, 244, although here the mortgagor could not prove such a shortfall.

201 ELG Tyler (ed) Fisher \& Lightwood's Law of Mortgage (10 ed, Butterworths, London, 1988) 369. 
refusal to embark on adventures and speculations, such as operating an existing mine, qualify. ${ }^{202}$ More generally, mortgagors cannot involve the courts in minute inquiries over what income might have been achieved. ${ }^{203}$ Nor can they stand idly by while their land is under-utilised only to claim an inflated account; they must help the mortgagee maximise their land's productivity. ${ }^{204}$

\title{
E The Unique Duty Owed When Selling Mortgaged Property
}

\section{Why is this duty treated separately?}

The paring of this duty from the general duties owed by mortgagees and receivers was finalised by Cuckmere Brick. ${ }^{205}$ Here, a mortgagee sold mortgaged land without publicising that planning permission for flats had been granted. The English Court of Appeal reviewed numerous cases in which mortgagees were supposedly liable for such carelessness. For example in Wolff $v$ Vanderzee, a mortgagee in possession sold land with its rent wrongly noted as 150, instead of 182, pounds per year, Vice Chancellor Stuart said that a mortgagee in possession holds a "position of responsibility", and if "he fails to take every proper precaution to secure the best price, his conduct is equivalent to wilful neglect and default." 206 In National Bank of Australasia v United Hand-in-Hand and Band of Hope Co, a mortgagee sold the mortgagor's property for 6,000 pounds after rejecting 8,000 pounds. The Privy Council said that the mortgagee would be charged for any shortfall, "owing to the want of due care and diligence." 207

In Cuckmere Brick, Lord Justice Salmon said of these cases, "[i]t would seem therefore that many years before the modern development of ... negligence, the courts of equity had laid down a doctrine in relation to mortgages which is entirely consonant with the general principles [of negligence]." 208 Cuckmere Brick translated this equitable doctrine into contemporary parlance; the mortgagee's "position of responsibility" equated to being the mortgagor's "neighbour" (in the Donoghue v Stevenson ${ }^{209}$ sense), and equity's variously

\author{
202 Hughes $v$ Williams (1806) 12 Ves Jun 494. \\ 203 ELG Tyler (ed) Fisher \& Lightwood's Law of Mortgage (10 ed, Butterworths, London, 1988) 369. \\ 204 Hughes $v$ Williams (1806) 12 Ves 493. \\ 205 Cuckmere Brick Co Ltd v Mutual Finance Ltd [1971] 1 Ch 949 (CA). \\ 206 Wolff v Vanderzee (1869) 20 LT 353, 354. \\ 207 National Bank of Australasia v United Hand-in-Hand and Band of Hope Co (1879) 4 App Cas 391, 411 \\ per Sir James W Colville. \\ 208 Cuckmere Brick Co Ltd v Mutual Finance Ltd [1971] 1 Ch 949, 967 (CA). \\ 209 Donoghue v Stevenson [1932] AC 562 (HL), per Lord Atkin.
}


described duty to "take every possible precaution" and exhibit "due care and diligence", became the duty of "reasonable care" that is negligence's hall-mark. Mortgagees and receivers were therefore subjected to a duty, grounded in negligence, to take reasonable care to get a "proper price" upon sale.

But arguably the Court misinterpreted or misapplied many of the cited precedents. Some cases contained clear statements that mortgagees should be liable only if guilty of some mental culpability higher than carelessness. ${ }^{210}$ In other cases, including Wolff and National Bank of Australasia, the duty stricter than good faith was imposed simply because the case dealt with the established liability to account for wilful default. ${ }^{211}$

Furthermore, Cuckmere Brick's creation of a new, negligence-based duty would have been unnecessary if the Court had taken the subsequently suggested view that the duty to get a proper price is part of the duty of good faith. ${ }^{212}$ Although cases such Re B Johnson $\mathcal{E}$ Co (Builders) Ltd decreed that a duty of good faith could not oblige someone to get the best possible price, ${ }^{213}$ it could still oblige someone to carefully pursue a proper price. Thus the protection afforded to mortgagors by Cuckmere Brick could arguably have been achieved through established equitable duties instead. ${ }^{214}$

Rightly or wrongly, Cuckmere Brick separated from the equitable duty of good faith a more onerous duty of reasonable care upon sale. Although Downsview established that this

210 For example, the cited case of National Bank of Australasia $v$ United Hand-in-Hand and Band of Hope Co (1879) 4 App Cas 391, 409 (PC), where the need for "wilful" negligence or default was emphasised; Tomlin $v$ Luce (1889) 41 Ch D 573, 575 (affirmed (1889) 43 Ch D 191 (CA)) per Kekewich J, where it was said that only oppression or dishonesty would attract liability. See generally Peter Devonshire "The Mortgagee's Power of Sale: A Case for the Equitable Standard of Good Faith" (1995) 46 NILQ 182, 193.

211 The same was true of Marriott $v$ The Anchor Reversionary Co (1861) 3 De GF\&J 177 (mortgagee raced ships to their detriment) and McHugh v Union Bank of Canada [1913] AC 299 (PC) (mortgagee drove horses until some died).

212 Forsyth $v$ Blundell (1973) 129 CLR 477, 481 per Menzies J dissenting on the application of the test to the facts (HCA). See the recent statements supporting this proposition in Moritzson Properties Ltd $v$ McLachlan [1994] 3 NZLR 250, 255 per Fraser J (HC). But compare Edward Sykes and Sally Walker The Law of Securities (5 ed, Sydney, Law Book Co, 1993) 119 describing Menzies J's conclusion as "rather remarkable".

213 In Re B Johnson \& Co (Builders) Ltd [1955] Ch 634, 662 per Jenkins LJ (CA).

214 But see S Robinson "Lenders' (and Receivers') Liability When Selling: The Need to Resort to Basic Principles" (1994) 68 ALJ 206, suggesting that the duty of good faith would not provide sufficient protection. 
duty lay in equity, not negligence, Lord Templeman missed the opportunity to re-associate the two duties. 215

\section{New Zealand's statutory formulation of the duty upon sale}

In New Zealand, both receivers and mortgagees in possession must take reasonable care to obtain the "best price reasonably obtainable at the time of sale". ${ }^{216}$ What amounts to reasonable care will vary from case to case. ${ }^{217}$ Mortgagees owe this duty to the "mortgagor", which by statutory definition includes subsequent encumbrancers. ${ }^{218}$ However, receivers owe their duty to the mortgagor, persons claiming through the mortgagor (including subsequent encumbrancers, but probably not shareholders ${ }^{219}$ or beneficiaries ${ }^{220}$ ), plus the mortgagor's unsecured creditors and suretors. ${ }^{221}$ A mortgagee's duty to these additional people is governed solely by their duty of good faith.

The choice of when to sell is probably governed by the fundamental duties described above. ${ }^{222}$ This will probably not oblige mortgagees or receivers to delay their sale in

215 Downsview Nominees v First City Corporation [1992] 1 NZLR 513, 524 (PC).

216 PLA 1952, s 103A; RA 1993, s19 (see also the previous formulation in the Companies Act 1955, s 345B). The difference in terminology from Cuckmere Brick's "proper price" is insignificant: Nathan Securities Ltd $v$ Stavefield Holdings No 29 Ltd (1994) ANZ Conv R 90, 91 per Hardie Boys J (CA).

217 For a list of sixteen possible requirements see Young, above n 31, para 23.15, 382-383.

218 PLA 1952, s 2 "mortgagor" includes anyone entitled to redeem a mortgage, and subsequent mortgagees can redeem a prior mortgage. Compare Young, above n 31, para 23.14, 381 who does not believe subsequent encumbrancers are included.

219 Rogers v Bullen (1992) 6 NZCLC 67,636, 67,642 per Holland J (HC). But compare Andrew Beck and Andrew Borrowdale Guidebook to New Zealand Companies and Securities Legislation (6 ed, CCH New Zealand Ltd, Auckland), para 1314, 382.

220 Parker-Tweedale v Dunbar Bank Plc [1991] Ch 12 (CA).

221 RA 1993, s 19.

222 Blanchard and Gedye, above n 39, para 11.32, 310. But compare Frances Xavier "Should a Mortgagee Owe a Duty of Care in Considering Whether or Not to Exercise its Power of Sale?" [1993] Qld LSJ 109, 118. 
anticipation of improved market conditions, ${ }^{223}$ although the contrary has been suggested. 224

\section{F Downsview Revisited in Medforth v Blake}

In Medforth $v$ Blake, ${ }^{225}$ receivers of a pig-farming company bought feed without taking advantage of readily available discounts for bulk purchases. They argued that under Downsview they could be liable only if their actions were not in good faith. But Sir Richard Scott VC held that Downsview was authority only for the proposition than a receiver's duties lie in equity, ${ }^{226}$ and the exact equitable duty applied would vary from case to case. Here, the applicable duty was said to be managing the property with "due diligence and care", and accordingly the receivers were liable.

The next section seeks to place these recent changes to the duties of mortgagees and receivers in their historical context.

\section{G Equity's On-Going Development}

Earlier sections recounted how equity has oscillated between rules favouring a mortgagor's right to recover their property 227 and rules favouring a mortgagee's right to enforce their security. ${ }^{228}$ Cuckmere Brick, Downsview and Medforth neatly illustrate how the see-saw between these competing rights continues today.

\section{Three decades of redefining equitable duties}

Cuckmere Brick tilted the balance towards the mortgagor by founding the duty upon sale in negligence, thereby opening the door to the general doctrine of negligence-based

223 Henry Roach (Petroleum) Pty Ltd v Credit House (Vic) Pty Ltd [1976] VR 309, 313 per Lush J (Vic:SC); Countrywide Banking Corporation v Robinson [1991] 1 NZLR 75, 77 per Cooke P (CA); Garden City Developments Ltd $v$ Cavell Leitch Pringle \& Boyle Nominees Ltd (28 April 1993) unreported, Court of Appeal, CA 63/93 (CA); Tse Kwong Lam v Wong Chit Sen [1983] 3 All ER 54, 59 per Lord Templeman (PC).

224 See Peter Devonshire "The Mortgagee's Power of Sale: New Perspectives on an Old Theme" (1995) 16 NZULR 251, 262-264.

225 Medforth v Blake [1999] 3 All ER 97 (CA) [Medforth].

226 The Court had earlier declined an invitation to criticise Downsview: see Yorkshire Bank Plc v Hall [1999] 1 ER 897 (CA).

227 For example, equity's creation of an equitable right of redemption and holding mortgagees in possession to account on the footing of wilful default.

228 For example, equity's refusal to undermine a mortgagee's legal right to possession, encouragement of the use of private receivership to circumvent the liability for wilful default, and the various rules softening the application of this liability. 
recovery later embraced by the New Zealand Court of Appeal. ${ }^{229}$ The Privy Council then condemned this idea in Downsview, restoring a historic advantage of receivership over possession: whereas the liability for wilful default restricted what a mortgage in possession could do with mortgaged property, their appointed receivers, owing only a duty of good faith, enjoyed a wider spectrum of management options. For instance, under Downsview a receiver could ignore freely available discounts on feed whereas a mortgagee in possession could not, and could generally pursue recovery of the mortgagee's loan with far greater ignorance of other parties' interests than could a mortgagee in possession.

To Sir Richard Scott, Downsview swung the balance too far in the mortgagee's favour: if a mortgagor could hold mortgagees to account for their wilful default, why should they have to suffer fools as receivers? A new rule permitting mortgagors to recover for mismanagement was needed. Downsview had forbidden the use of negligence for this purpose, but by cleverly limiting Downsview's ratio, a similar result was developed in equity. Medforth thus imposed on English receivers a standard of care similar to that arising from a mortgagee in possession's liability for wilful default. This effect is lost in New Zealand, however, because receivers' duties are now statute-based. ${ }^{230}$

\section{Future developments}

The tension between Downsview and Medforth may resolve itself in one of two ways: either a higher authority will reinstate good faith as the fundamental duty of all receivers (thus reaffirming Downsview and In Re B Johnson $\mathcal{E}$ Co (Builders) Ltd), or else Medforth will be used to attack other duties presently defined by good faith alone. In New Zealand, good faith remains the only duty owed before the remedies of possession or sale are exercised and so Medforth provides ammunition for arguing that decisions such as the choice of receiver and timing of sale should be governed by a duty more stringent than good faith.

The next section investigates whether the current differences in duties are of practical significance to mortgagees.

\section{H How Do the Differences in Duties Impact the Choice of Remedy?}

In summary, mortgagees must avoid oppressive conduct, act in good faith (a general duty threatened by Medforth) and, upon entering into possession, avoid behaviour amounting to wilful default. ${ }^{231}$ The benefactors of these duties vary, but do not extend

229 First City Corporation v Downsview Nominees Ltd [1990] 3 NZLR 265 (CA).

230 RA 1993, ss 18, 19.

231 Interestingly the New Zealand Bankers' Association's Code of Banking Practice advocates a standard of care more stringent than that required by law, stating that banks will act "fairly" and 
beyond the mortgagor, subsequent encumbrancers, guarantors and suretors. In contrast, a mortgagee's appointed receiver must act in good faith and, to the extent consistent with that duty, have reasonable regard to the interests of others, including a potentially long list of unsecured creditors. Both groups owe an identical duty upon sale, but again a receiver's duty is owed to more people. Additionally, there are statutory procedures in place for challenging a receiver's actions which do not exist for mortgagees in possession.

The question is whether these differences translate into any appreciable advantages for receivership or possession. The answer lies in investigating whether, in light of their duties, mortgagees in possession or receivers enjoy greater freedom with respect to when and how their powers may be exercised. On this criteria receivership was the better option under Downsview because receivers did not suffer any restriction akin to a mortgagee in possession's need to act without wilful default. But the recent imposition of statutory duties based on negligence principles has reigned in receivers' freedom to act to a level similar to that of mortgagees in possession. Receivers now have a (secondary) duty to regard numerous parties' interests, owe their duties to more people, and can have their actions judicially challenged by various parties. In theory, ${ }^{232}$ this could preclude many courses of action previously open to them under Downsview. These extra duties also mean that prudent receivers should spend time checking and recording the interests of numerous people and seeking the court's blessing before embarking on potentially risky ventures. ${ }^{233}$ Both these tasks will delay the exercise of a receiver's powers in a manner not experienced by mortgagees in possession.

Thus one can say with certainty that New Zealand's recent law changes have diminished one of the advantages that mortgagees gained through receivership: the ability to have the mortgaged property used in a variety of ways conducive to the quick and full recovery of their loan.

The next section outlines the various liabilities which also guide the exercise of a mortgagee or receiver's powers.

\section{LIABILITIES}

This section investigates the differences between the costs for which receivers and mortgagees in possession are prima facie responsible for paying. Ultimately most of these

"reasonably". See Mark Russell, Stuart Walker \& John King (eds) "New Zealand" (1997) 8 J Banking Law \& Practice 86.

232 The question of whether the actual practice of receivers has been changed by the RA 1993 would require empirical research and is not pursued here.

233 RA 1993, s 34. 
costs will be brought home to the mortgagor through an implied or contractual indemnity. Receivers, as agents, are automatically indemnified by the mortgagor for all personal liabilities ${ }^{234}$ except those, "incurred in consequence of [their] negligence or default".235 Mortgagees in possession, in contrast, can only receive an indemnity through contract.

\section{A Liability to Third Parties for Contractual Debts}

Both groups are personally liable for new contracts they make and for existing contracts of the mortgagor they adopt. ${ }^{236}$ There are four main exceptions. First, only mortgagees in possession, as deemed reversioners, ${ }^{237}$ automatically inherit the burden of leasehold covenants which touch and concern the land. ${ }^{238}$ Secondly, both groups are liable for paying the mortgagor's rent, ${ }^{239}$ although mortgagees in possession need only pay rent out of income from the land. ${ }^{240}$ Thirdly, receivers are personally liable for meeting the mortgagor's hire-purchase payments. ${ }^{241}$ Mortgagees in possession, if they wish to use the mortgagor's hired property, will have to negotiate a separate hire-purchase contract. Fourthly, if a mortgagee in possession wishes to retain employees' services they will be personally liable for all an employer's obligations, including paying wages and salaries. This is because entry into possession of a business terminates all employment contracts, $^{242}$ meaning that subsequent employment must be under new contracts. Thus a mortgagee in possession acquires all the statutory obligations of an "employer", 243 and is

234 Just as any agent is entitled to an indemnity from their principal: Adamson v Jarvis (1827) 4 Bing 66; Thacker $v$ Hardy (1878) 4 QB 685.

235 RA Price Securities Ltd v Henderson [1989] 2 NZLR 257, 265 per Somers J (CA).

236 Halsbury's Laws of England (4 ed, Butterworths, London, 1980) vol 32, Mortgage, para 693, 316; RA 1993, s 32(1)

237 PLA 1952, s 91(11).

238 PEA Swift Investments v Combined English Stores Group Plc [1989] 1 AC 632 (HL). Covenants personal to the landlord mortgagor will not pass.

239 Compare the position under the general law Re J W Abbott $\mathcal{E}$ Co (1913) WN 284 (entry into possession does not imply a willingness to pay the mortgagor's rents); Rangatira Proprietary Ltd $v$ Viola Hallam Ltd [1957] NZLR 1188, 1191 per Shorland J (SC) (dealing with receivers).

240 Compare LTA 1952, s 110 and RA 1993, s 32(5). A receiver's personal liability is limited to rent accruing after the receivership's fourteenth day: RA 1993, s 32(6).

241 RA 1993, s 32(5). Again this liability is limited to fees accruing after the receivership's fourteenth day: RA 1993, s 32(6).

242 Reid $v$ The Explosives Company Ltd (1887) 19 QBD 264, 267 per Lord Esher MR (although these statements were obiter dicta as the case concerned court-appointed receivers).

243 For example, purchasing insurance against work-place accidents: Accident Insurance Act 1998, s 169. 
liable for breaching any term of their employment contracts. In contrast, receivers are only liable for employees' salary and wages ${ }^{244}$ and, unless they hire or re-hire employees, or adopt existing employment contracts, are not liable for breaching other terms in the employees' contracts.

\section{B Liability to Third Parties in Tort}

Both groups are personally liable for their own torts such as trespass, nuisance or conversion. ${ }^{245}$ Additionally, when repudiating or otherwise preventing the performance of a mortgagor's existing contracts, mortgagees in possession risk liability for the tort of inducing breach of contract. Receivers who act within their powers and duties are generally immune from this tort because agents cannot be liable for causing their principals to breach contracts. ${ }^{246}$

\section{Liability for Breach of Duty}

Both groups are personally liable to pay all costs, including damages awarded to injured parties, associated with breaching their duties.

An important development in this area concerns the possible erosion of the rule that mortgagees are not liable for their receivers' misconduct. ${ }^{247}$ In recent years the suggestion has arisen that mortgagees may be liable for appointing incompetent receivers, ${ }^{248}$ and may further be liable if, in breach of their duty of good faith, they fail to use their power to remove a receiver guilty of gross misconduct. In Dawson $v$ Southern Communications (1979) $L t d$, Master Towle theorised that in "extreme circumstances" a receiver's appointor could be liable for failing to remove a receiver who "acted dishonestly or with total neglect of his responsibilities." 249 This would widen a mortgagor's ability to recover damages for the

244 "Wage" has been given a wide definition: Re R McGaffin Ltd [1938] NZLR 764 (SC), where it was held to include sums agreed to be paid for living or other expenses. Receivers can avoid any such liability by notifying employees of their termination within the receivership's first fourteen days: RA 1993, s 32((1)(b). For the notice's requirements see Re Weddel New Zealand Ltd [1998] 1 NZLR (CA).

245 LNZ Receivers, above n 85, para 51, 56.

246 Said v Butt [1920] 3 KB 497; Lathia v Dronsfield Bros Ltd [1987] BCLC 321, 324. However, receivers may be liable if the third party can establish a proprietary interest in the contractual property, see Telematrix Plc $v$ Modern Engineers of Bristol (Holdings) Plc [1985] BCLC 213, receivers joined as parties due to possible tort liability for threatening to repudiate contract granting creditor a lien over meat.

247 American Express International Banking Corporation v Hurley [1985] 3 All ER 564, 571 per Mann J.

248 Shamji v Johnson Matthey Bankers Ltd [1986] BCLC 278, 283 per Hoffmann J.

249 Dawson v Southern Communications (1979) Ltd (1992) 6 NZCLC 68,123, 68,130 (HC). 
mismanagement of their property, and is further evidence that in its ongoing search for balance equity is currently re-emphasising the rights of mortgagors.

\section{Other Specific Liabilities}

\section{Liability for rates}

Entry into possession does not cause a mortgagor's obligation as landowner to pay rates to cease, ${ }^{250}$ but first mortgagees are answerable for a mortgagor's unpaid rates. ${ }^{251}$ Receivers are only liable for rates if they dispossess the mortgagor of the land so as to acquire the status of an "occupier". 252

\section{Liability for occupation rent}

Mortgagees in possession who occupy the land may be charged an occupation rent. Whereas it was once thought that "if a mortgagee enters into possession of the lands, he is always charged with the utmost value they are proved to be worth", 253 this gave way to the current wisdom that the occupation rental need only be "fair" 254 and indeed will be nothing if the property has no rental value. ${ }^{255}$

Receivers, as agents of the mortgagor, are not liable for rent. 256

\section{Potential liability as a "shadow director"}

If a corporate mortgagor is allowed to continue operating their business from the land, a mortgagee in possession or receiver should refrain from directing the mortgagor's

250 See the term in the PLA 1952, Fourth Schedule, cl 3, implied into every mortgage unless negatived by the PLA 1952, s 78 .

251 Rating Powers Act 1988, s 139(1). Although they can reclaim these expenditures from the mortgagor, see Rating Powers Act 1988, s 139(4). See also PLA 1952, Fourth Schedule, cl 7, implying this term into every mortgage unless negatived.

252 Ratford v Northavon District Council [1986] 3 All ER 193, 208 (CA). See generally Hubert Picarda The Law Relating to Receivers, Managers and Administrators (2 ed, Butterworths, London, 1990) 182-184.

253 Lord Trimleston v Hamill (1810) 1 Ball \& B 377, 385 per the Irish Lord Chancellor.

254 Metcalfv Campion (1828) 1 Mol 238, 239 per Lord Hart LC.

255 Marshall v Cave (1824) 3 LJOS Ch 57 (ruinous state prevented beneficial occupation); Fyfe v Smith [1975] 2 NSWLR 408; White v City of London Brewery Co (1889) 42 Ch D 237 (CA) (no occupation rent was chargeable while the mortgaged pub's depressed state precluded rental).

256 Waitemata Electric Power Board v Mills [1971] NZLR 630 (SC). 
conduct lest they be deemed a shadow director, ${ }^{257}$ attracting the duties, obligations, and potential fines inflicted upon directors by the Companies Act $1993 .{ }^{258}$

\section{E How Do the Differences in Liabilities Affect the Choice of Remedy?}

The primary advantage of receivership, in terms of liabilities, is that it allows the mortgagee to shift the burden of liabilities onto a third party receiver. However, this benefit is tempered by the recent suggestion that a mortgagee cannot turn a blind eye to their receiver's misconduct, and in exceptional cases may be liable for failing to halt obvious injustice. ${ }^{259}$

Additionally, whereas previously mortgagors were liable for their existing contracts plus new contracts made by receivers, ${ }^{260}$ under the Receiverships Act 1993 receivers are personally liable for new contracts, rent, wages, and hiring fees. Therefore third parties' claims against the mortgagor, which once ranked as unsecured debts to be satisfied from the mortgaged property only after the mortgagee had recouped their loan, are now paid by receivers, who in turn, due to their implied indemnity for personal liability, take these sums from the mortgaged assets in prioirty to the mortgagee's claim. ${ }^{261}$ A receiver's equitable lien (arising from their indemnity) even permits them to retain possession of the mortgaged property until their claim is realised, since " equity will never take [charged property] out of the hands of a [receiver] without seeing that ... he is relieved from personal liability in respect of them ."262 Thus the Receiverships Act 1993, by indirectly allowing wages, rents, fees and other contractual expenses to be paid out of the mortgaged property ahead of the mortgagee's loan, increases the risk that the mortgagee's security will be insufficient. This is another example of how recent changes to the law have undermined the traditional advantages of receivership.

Nevertheless, possession still yields a potentially wider range of personal liabilities than does receivership: mortgagees in possession may have to pay rates and occupation rent, may inherit the mortgagor's obligations under leasehold covenants (such as repair),

257 "Director" includes someone who controls the exercise of the Board's powers: Companies Act 1993, s 126(1)(b).

258 See generally James O'Donovan "Banks as Shadow Directors" (1995) 25 VUWLR 285.

259 See above subsection VII C: Liability For Breach of Duty.

260 D Owen \& Co v Cronk [1895] 1 QB 265 (CA).

261 Moodemere Pty Ltd $v$ Waters (1988) 5 ACLC 790 (Vic:SC).

262 Jennings v Mather [1902] 1 KB 1, 6 per Stirling LJ (CA). See also Mellor v Mellor [1992] 4 All ER 10, 20 per Hart QC; Hill v Venning (1979) 4 ACLR 555 (Qld:SC). But the indemnity only relates to established, not contingent, debts: Dyson v Peat [1917] 1 Ch 99. 
may acquire the full responsibilities of being an "employer", and are more easily found guilty of inducing breaches of contract. As the total dollar value of these personal liabilities increases, so does the possibility that the mortgaged property will be insufficient to cover them, causing direct loss for even fully-indemnified mortgagees.

Ultimately, in terms of liability, receivership continues to be the more attractive option as prima facie liability for expenditure is shifted to a third party, and the additional personal liabilities associated with possession are avoided. But this subsection, and indeed, the whole article, has hopefully shown that the advantages of receivership have been greatly diluted.

\section{CONCLUSIONS}

A primary goal of this article was to re-evaluate the institutionalised mantra that receivership is the superior remedy to possession. The inescapable conclusion is that the recent changes to New Zealand law, and in particular the Receiverships Act 1993, eroded the pillars upon which that mantra stood. Today, receivers operate under duties which restrict the range of uses to which they can put mortgaged property, curtailing their freedom in a manner similar to that experienced by mortgagees in possession through their liability for wilful default. The imposition of personal liability upon receivers has, through the operation of their agent's indemnity, increased the risk that a mortgagee will see the value of their security whittled away by what were previously unsecured, inferior debts. There is also judicial dicta that mortgagees may sometimes be responsible for their receivers' misconduct, further dispelling the idea that by opting for receivership mortgagees wash their hands of potential liability.

This article has also drawn attention to the particular circumstances in which entry into possession may be preferable in light of the remedy's attendant rights and powers, such as the power to run the mortgagor's business, demand vacant possession, and repudiate certain contracts. Additionally, considerations arising from the disparate laws relating to the initiation of each remedy may also, depending on the facts, make receivership impractical or impossible to invoke. With the erosion of the some of the traditional advantages of receivership, these considerations may play a greater role in determining a mortgagee's choice of remedy.

Secondly, this article has highlighted the fascinating battle between competing equitable considerations that has shaped mortgage law. Through Downsview and Medforth, the balancing process continues, and while of limited relevance in New Zealand, the future reconciliation of these two cases may yet impact upon the duties, and thus conduct, of mortgagees. 
Finally, given the simultaneous review of the laws of mortgagee possession and receivership, and the obvious attempts to apply similar rules to both ${ }^{263}$ (particularly in terms of regulatory provisions), it is disappointing that this article has revealed several unjustifiable inconsistencies. Differences in entitlement, notification requirements, reporting requirements, personal qualifications, rights to essential services, and the availability of judicial controls have all been identified as requiring rectification. These differences, in addition to the aforementioned effect the Receiverships Act 1993 has had on a mortgagee's choice of remedy, plus that Act's failure to distinguish between corporate and non-corporate receiverships, leads to the suspicion that this legislation was introduced without thoroughly analysing its consistency with other laws and its effect upon mortgagee practice. Perhaps the mantra of receivership's superiority is to blame: by characterising mortgage possession as inferior, the laws of mortgagee possession slipped into relative obscurity and possibly, to the drafters of the Receiverships Act 1993, unimportance. Hopefully a greater appreciation of the historical connections between these bodies of law might remedy that type of thinking.

263 Many of the provisions in the Part VIIA of the Property Law Act 1952 mirror word-for-word the provisions in the Receiverships Act 1993. 